\title{
Narracja a tożsamość - przypadek Rolanda Barthes'a*
}

ABSTRACT. Adam Dziadek, Narracja a tożsamość - przypadek Rolanda Barthes’a [Narration and identity - the case of Roland Barthes]. "Przestrzenie Teorii" 3/4, Poznań 2004, Adam Mickiewicz University Press, pp. 101-114. ISBN 83-232-1454-9. ISSN 1644-6763.

The author makes an attempt at an analysis of the original text "Roland Barthes par Roland Barthes" from the point of view of narration and identity. The fundamental question emerging from the analysis of the text is that of how it is possible to write about oneself at all, writing an autobiography and what obstacles are presented to this kind of writing by language itself and by history. This is proven by unequivocal analyses of personal forms appearing and playing a special role in "RB par RB".

Chcę mówić o szczególnym i bardzo nietypowym przypadku tekstu, w którym narracja splata się z problemem tożsamości w intrygujący sposób - Roland Barthes par Roland Barthes ${ }^{1}$. Jeśli w tytule mojego tekstu pojawiło się imię i nazwisko „Roland Barthes”, to od razu warto podkreślić, że jest ono wieloznaczne, odnosi się bowiem do wielu różnych Rolandów Barthesów, którzy krążą w skupieniu i rozproszeniu po tej niezwykłej książce, jaką jest $R B$. Książkę tę określano dotąd rozmaicie: część badaczy, wśród nich m.in. Carlo Ossola, skłonnych jest uznawać ją za pierwszą część "trylogii autobiograficznej”" (pozostałymi częściami mają być wg Ossoli Fragmenty dyskursu miłosnego i La chambre claire), Krzysztof Kłosiński nazwał ją kilka lat temu „patchworkiem o sobie”, zaś Marianne Alphant, idąc za wskazówkami autora, powiedziała o niej „prawie powieśc”"4.

To niewielkie dziełko jest bez wątpienia jedną $\mathrm{z}$ najciekawszych narracji o sobie, jaka kiedykolwiek została napisana. Celowo określam $\mathrm{w}$ ten

* Tekst wygłoszony na XXXII Konferencji Teoretycznoliterackiej „Narracja i tożsamośc. Współczesne problemy antropologii literatury" zorganizowanej przez Katedrę Antropologii Literatury i Badan Kulturowych IP UJ oraz Pracownię Poetyki Historycznej IBL PAN. Janowice 27 IV-1 V 2004.

1 R. Barthes, Roland Barthes par Roland Barthes. Wszystkie cytaty z tej pracy podaję za: Idem, Oeuvres complètes, Paris 2002, t. 4, 575-771. Dalsze odwołania do Oeuvres complètes podaje $\mathrm{z}$ oznaczeniem OC i wskazaniem numerów odpowiednich tomów oraz stron.

2 Por. np. C. Ossola, "L'Humanite" 24 X 2000.

${ }^{3} \mathrm{~K}$. Kłosiński, Patchwork o sobie: Roland Barthes, w: Osoba w literaturze i komunikacji literackiej, red. E. Balcerzan i W. Bolecki, Warszawa 2000, s. 73-83.

${ }^{4}$ M. Alphant, Presque un Roman. W: $R / B$. Roland Barthes, red. M. Alphant, N. Léger, Paris 2002, s. 125-128. 
sposób, nie chcąc użyć nazwy gatunkowej „autobiografia”, która w odniesieniu do tej niezwykłej książki byłaby zupełnie nietrafna, autor bowiem konsekwentnie stara się wykraczać poza ramy tego gatunku.

$R B$ ukazała się po raz pierwszy nakładem Éditions du Seuil w 1975 roku, w serii Écrivains de toujours [Pisarze wszechczasów] poświęconej znanym pisarzom i filozofom (sam Barthes jest autorem Michelet par luimême - pozycji wydanej w ramach tej serii w 1954 roku). Kompozycja książek wydawanych w ramach serii opierała się zawsze na wypowiedzi krytyka uzupełnionej wypisami z dzieł danego autora. W całej serii Pisarze wszechczasów Roland Barthes par Roland Barthes stanowi zresztą przypadek szczególny, jest bowiem jedyną pozycją spełniająca formułę „par lui-même” [,sam o sobie”].

Opis tej nietypowej narracji o sobie samym można zacząć od wyznaczników formalnych. Książkę otwiera zamieszczony na okładce jeden z wielu barthesowskich "koloraży" (napisał nawet na ich temat krótki szkic pt. Le degré zéro du coloriage [Poziom zero kolorażu $]^{5}$ - „koloraż”, to coś pomiędzy rysunkiem, malarstwem, graffiti i pismem - coś, co jest nieprzedstawieniowe, nieciągłe) i odręczny - niezwykle znaczący - zapisek na osobnej stronicy: „Tout ceci doit être considéré comme dit par un personnage de roman" [„Wszystko to trzeba uznać za wypowiedź bohatera powieści."] [OC, t. 4, s. 577]. Dalej pojawia się opatrzona tytułem $O b$ razy [Images] seria zdjęć, którą otwiera zdjęcie matki autora, a zamyka zdjęcie Barthes'a zapalającego papierosa z podpisem "Mańkut” [„Gaucher"]. Sa to fotografie wyselekcjonowane zgodnie z przyjętą przez autora i obowiązującą w całej książce regułą wyobraźni [l'imaginaire] (to co było w rzeczywistości, ale jest już teraz nierzeczywiste, nierealne). Tym samym zdjęcia układają się w odrębny i podrzędny wobec całości system narracyjny, zwłaszcza, że każde z nich opisywane jest w specyficzny sposób, np. stara fotografia przedstawiająca Bayonne (rodzinne miasto Barthes'a) opisana jest, rzec by można, na sposób powieściowy (w opisie tym zwraca uwagę powtórzenie samej nazwy Bayonne oraz innych nazw miejscowych - dzieje się tu tak, jakby wymawianie tych nazw wprowadzało do tekstu porządek związany z przyjemnością ich słuchania; nazwy te $w$ porządku anamnezy ewokują całe ciągi skojarzeniowe, rozmaite wspomnienia):

Bayonne, Bayonne, ville parfaite: fluviale, aérée d'entours sonores (Mouserolles, Marrac, Lachepaillet, Beyris), et cependant ville enfermée, ville Romanesque:

5 R. Barthes, Le degré zéro du coloriage, w: tegoż, Oeuvres complètes. Paris 2002, t. 5, s. 453. Dalsze odwolania do Oeuvres completes podaję z oznaczeniem OC i wskazaniem numerów odpowiednich tomów oraz stron. 
Proust, Balzac, Plassans. Imaginaire primordial de l'enfance: la province comme spectacle, l'Histoire comme odeur, la bourgeoisie comme discours.

[Bayonne, Bayonne, miasto doskonałe: nadrzeczne, odświeżone brzmieniami nazw (Mouserolles, Marrac, Lachepaillet, Beyris), a jednak miasto zamknięte, miasto powieściowe: Proust, Balzac, Plassans. Świat pierwotnej wyobraźni dzieciństwa: prowincja jako widowisko, Historia jako zapach, mieszczaństwo jako dyskurs.]

[OC, t. 4, s. 584]

Zdjęcia-obrazy stanowią pierwszą, wprowadzającą część książki, przygotowują i płynnie stapiają się $\mathrm{z}$ drugą jej częścią zatytułowaną Fragmenty [Fragments] i skupioną na pisaniu. Obrazy wprowadzają w świat wyobraźni, a dokonuje się to poprzez uruchomienie punctum jako szczególnego sposobu ich oglądu. Jak pamiętamy, punctum (w odróżnieniu od studium, lektury kulturowej, bazującej na wiedzy osoby, która ogląda dany obraz) ma budzić niepokój, drażnić, angażować do lektury ciało wraz ze wszystkimi czynnikami właściwymi samemu patrzącemu podmiotowi, które są pozakulturowe. Punctum (ukłucie, dziurka, plamka i zarazem przypadek, który „punktuje” widza) wiąże się z „trzecim sensem" i pochodzi nie tyle z porządku lubię, ile z porządku kocham (czy nawet „uwielbiam”, ponieważ „kocham” niewystarczająco oddaje rozbudzone w widzu pożądanie) ${ }^{6}$. Punctum łączy się z „trzecim sensem”, tym, który wyłania się $\mathrm{z}$ danego obrazu lub tekstu jako sens dodatkowy, suplementarny, sens wyłaniający się w trakcie lektury w formie „nadwyżki”. Ten trzeci sens wykracza poza kulturę, wiedzę i informację, wykracza zatem poza komunikat i otwiera się na nieskończoność języka. Jest on zawarty wewnątrz aktu interlokucji, a jednocześnie znajduje się na zewnątrz języka artykułowanego. W sposób szczególny utrudnia on wytworzenie metajęzyka, jest bowiem nieciągły, obojętny na historię i sens intencjonalny. Sens ten sprawia, że lektura zostaje zawieszona pomiędzy obrazem a opisem, pomiędzy definicją a przybliżeniem [OC, t. 3, s. 500]. Tak oto za pośrednictwem zdjęć zawartych w pierwszej części $R B$ dokonuje się wkroczenie w świat wyobraźni.

Część Fragmenty otwiera zapisek o takiej treści: „Drzewa są alfabetami, mówili Grecy. Pośród wszystkich drzew-liter najpiękniejsza jest palma. Obok nadmiaru i wyrazistych odrośli, palma posiada również tę cechę pisania, którą jest opadanie". Tuż obok pojawia się w formie motta znany i jednocześnie, jak wolno się domyślać, jeden $\mathrm{z}$ ulubionych przez Barthes'a, wiersz Heinego:

${ }^{6}$ R. Barthes, La chambre claire, w: OC, t. 5, s. 809 i 810. 
Ze skał północnych korony

Samotna sosna się wzbija.

Senno jej; w białe osłony

I śnieg i lód ją obwija.

O palmie śni dalekiej,

Która we wschodniej krainie

Milcząc usycha od spieki,

Samotna na skał wyżynie.

Koloraże, zdjęcia, fragment Heinego, ułożone w porządku alfabetycznym fragmenty tekstowe - wszystkie elementy współistnieją, nakładają się na siebie w tej nietypowej narracji o sobie. Raz jeszcze powtórzę, że niepodobna określić $R B$ mianem „autobiografii”, tym bardziej że ten gatunek Barthes uznawal za skrajnie narcystyczny, toteż zdecydowanie próbował się uwolnić od takiej formy mówienia o sobie, która wpychałaby go $\mathrm{w}$ gotowe schematy, w - posługując się w tym miejscu jego własnym językiem - wypowiedzi przewidywalne. Jedną z części zamykających całość $R B$ jest biografia ujęta w formę datowanego zbioru ważniejszych wydarzeń z życia autora, pod nią zaś został wtrącony w nawias zapisek, następującej treści:

(Une vie: études, maladies, nominations. Et le reste? Les rencontres, les amitiés, les amours, les voyages, les lectures, les plaisirs, les peurs, les croyances, les jouissances, les bonheurs, les indignations, les détresses: en un mot: les retentissements? - Dans le texte - mais non dans l'oeuvre.)

[(Życie: studia, choroby, nominacje. A reszta? Spotkania, przyjaźnie, miłości, podróże, lektury, przyjemności, lęki, wierzenia, rozkosze, szczęście, oburzenie, zmartwienia: jednym słowem: oddźwięki? - W tekście - ale nie w dziele.)]

[OC, t. 4, s. 754]

Zapisek ten jest jak gorzka refleksja o życiu składającym się $\mathrm{z}$ jakichś drobiazgów, które - być może nawet ważne w samym życiu - wspominane w autobiografii mogłyby przyjąć jedynie postać owych „oddźwięków”. Czy zatem warto o nich pisać? Czy warto pisać autobiografię? Czy w ogóle możliwe jest jej napisanie?

Książka ta nie jest też powieścią, choć ostatecznie pewne jej znamiona można by w tym tekście wskazać. $R B$ zostaje określona przez autora jako Księga ego [Le livre du Moi] - w tym fragmencie pojawiają się ponownie słowa:

Tout ceci doit eter considéré comme dit par un personnage de roman - ou plutôt par plusieurs. Car l'imaginaire, matière fatale du roman et labyrinthe des redans dans lequels se fourvoie celui qui parle de lui-même, l'imaginaire est pris en charge par plusieurs masques (personae), échelonnés selon la profondeur de 
la scène (et cependant personne derrière). Le livre ne choisit pas, il fonctionne par alternance, il marche par bouffées d'imaginaire simple et d'accès critique, mais ces accès eux-mêmes ne sont jamais que des effets de retentissement: pas de plus pur imaginaire que la critique (de soi). La substance de ce livre, finalement, est donc totalement romanesque.

[Wszystko, co tu napisano, należy traktować jak wypowiedź postaci powieści albo raczej wielu postaci. Bowiem za wyobraźnię, fatalną materię powieści i labirynt uskoków, w których błądzi ktoś, kto mówi o sobie, odpowiada wiele masek (personae), poustawianych w głąb sceny (a za nimi nie ma nikogo). Księga nie wybiera, funkcjonuje na przemian, kroczy prostymi uderzeniami wyobraźni do glowy i przystępami krytyki, jednak te przystępy są zawsze tylko efektem oddźwięku: nie ma wyobraźni czystszej od krytyki (siebie). Substancja tej książki jest ostatecznie całkowicie powieściowa.]

[OC, t. 4, s. 695]

Jednak nie chodzi o to, aby stworzyć powieść, ale raczej „powieściowość" (le romanesque) lub efekt „powieściowości”, nie tworząc przy tym tekstu, który zostałby zamknięty w sztywnej formule gatunku, jakim jest powieść.

Czym więc jest ta książka? Odpowiedź podsuwa sam Barthes - jest to Tekst życia, życie jako tekst, oto słowa, które czytamy we fragmencie zatytułowanym Bogini $H$. [La déesse H.]:

Le pouvoir de jouissance d'une perversion (en l'occurrence celle de deux H.: homosexualité et haschisch) est toujours sous-estimé. La Loi, la Doxa, la Science ne veulent pas comprendre que la perversion, tout simplement, rend heureux; ou pour préciser advantage, elle produit un plus: je suis plus sensible, plus perceptif, plus loquace, mieux distrait, etc. et dans ce plus vient se loger la difference (et partant, le Texte de la vie, la vie comme texte). Dès lors, c'est une déesse, une figure invocable, une voie d'intercession.

[Siła rozkoszy perwersji (w tym wypadku dwóch H: homoseksualizmu i haszyszu) jest zawsze niedoceniana. Prawo, Doksa, Nauka nie chcą zrozumieć, że perwersja po prostu czyni szczęśliwym; lub, gwoli uściślenia, wytwarza ona pewnego rodzaju bardziej: jestem bardziej wrażliwy, bardziej spostrzegawczy, rozmowny, bardziej roztargniony, etc. $\mathrm{i}$ to właśnie $\mathrm{w}$ tym bardziej usytuowana jest różnica (i stąd właśnie wynika Tekst życia, życie jako tekst). Dlatego perwersja jest boginią, figurą wezwania, prośbą o wstawiennictwo.]

[OC, t. 4, s. 643]

Powiedziałem, że $R B$ jest nietypową narracją o sobie, nietypową choćby z tego względu, że w całym tekście rozsiane są fragmenty bezustannie kwestionujące prawdziwość danej wypowiedzi (chodzi nie tyle o fakty, ile o sposób ich wypowiadania i mówienia o nich). Świadomość 
językowa, która, nawiasem mówiąc, posunięta jest aż do granic możliwości i przez to wręcz chorobliwa: „Jestem chory: widzę język." [„J'ai une maladie: je vois le langage".] [OC, t. 4, s. 735] powiada Barthes i kwestionuje bezustannie zasadność mówienia o sobie, bezustannie powraca do problematyki skupionej wokół nietożsamości. Sprawę nietożsamości można tu wyjaśnić na wiele różnych sposobów, m.in. tak, że w całość wypowiedzi włącza się tu element fantazmatyczny. Na wypowiedź podmiotu nakłada się schemat imaginacyjny, a sam podmiot przedstawia dopełnienie nieświadomego pożądania?

$R B$ jest narracją o sobie, która przybiera formę lektury samego siebie opartą na fragmentach ${ }^{8}$. Warto zwrócić uwagę na fragment tej książki, który dotyczy właśnie fragmentu - jego tytuł brzmi Le cercle de fragments [Krag fragmentów] [OC, t. 4, s. 670-671]. Przytoczmy w tym miejscu kilka wybranych zdań owego fragmentu o fragmentach:

Écrire par fragments: fragments sont alors des pierres sur le pourtour du cercle: je m'étale en rond: tout mon petit univers en miettes; au centre, quoi? Son premier texte ou à peu près (1942) est fait de fragments; ce choix est alors justifié à la manière gidienne "parce l'incohérence est preferable à l'ordre qui déforme". Depuis, en fait, il n'a cessé de pratiquer l'écriture courte: tableautins des Mythologies et de l'Empire des signes, articles et préfaces des Essais critiques, lexies de $S / Z$, paragraphes titrés du Michelet, fragments du Sade II et du Plaisir du texte.

[Pisanie fragmentami: [ ...] cały mój mały świat w kawałkach; a co znajduje się w centrum? Jego pierwszy tekst lub coś podobnego (1942) jest zrobiony z fragmentów; ten wybór jest więc uzasadniony na sposób Gide’owski „ponieważ niespójność jest lepsza od porządku, który zniekształca". Odtąd rzeczywiście nie przestawał uprawiać pisania krótkiego: obrazki Mitologii i Imperium znaków, artykuły i przedmowy z Esejów krytycznych, leksje $S / Z$, tytułowane paragrafy Micheleta, fragmenty Sada II i Przyjemności tekstu.]

[OC, t. 4, s. 670]

Przyglądając się calości dzieła Barthes'a, rzeczywiście trzeba potwierdzić fakt, że kompozycja fragmentaryczna dominuje w większości jego prac. W Mitologiach sposób komponowania tekstu, sposób jego pisania zostaje wyłożony już w pierwszej części analitycznej zatytułowanej Siwiat wolnoamerykanki. Ten fragment nie jest jedynie analizą popular-

${ }^{7}$ Por. L'Apport freudien. Éléments pour une encyclopédie de la psychanalyse, red. P. Kaufmann, Paris 1998, s. 172.

${ }^{8}$ Kwestię fragmentarycznego charakteru pisarstwa Barthesa omawiam szerzej w: A. Dziadek, Sztuka mikrolektury Rolanda Barthes'a, w: Miniatura i mikrologia, red. A. Nawarecki, Katowice 2000, t. 1, s. 30-35. Por. także: B. Comment, Du fragment au tableau, w: tego ż, Roland Barthes, vers le neutre, Paris 2002, s. 163-184. 
nego widowiska wiodącą do wskazania złożonych mechanizmów nim rządzących, ale przede wszystkim wykładem metody, swoistym metatekstem objaśniającym sposób analizy, sposób pisania i sposób lektury. Barthes postrzega wolnoamerykankę jako następstwo fragmentów: „Wolnoamerykanka wymaga zatem natychmiastowej lektury sensów ułożonych obok siebie bez konieczności ich łączenia"9. Takich fragmentów metatekstowych jest w Ś wiecie wolnoamerykanki znacznie więcej, a koncentrują się one przede wszystkim na akcie czytania. Przyjrzyjmy się jeszcze innemu - bardzo ważnemu z mojego punktu widzenia - fragmentowi Kręgu fragmentów:

Non seulement le fragment est coupé de ses voisins, mais à l'intérieur de chacque fragment règne la parataxe. Cela se voit bien si vous faites l'index de ces petits morceaux; pour chacun d'eux, l'assemblage des referents est heteroclite; c'est comme un jeu de bouts rimes: „Soit les mots: fragment, cercle, Gide, catch, asyndète, peinture, dissertation, Zen, intermezzo; imaginez un discours qui puisse les lier". Eh, bien, ce sera tout simplement ce fragment-ci. L'index d'un texte n'est donc pas seulement un instrument de référence; il est lui-même un texte, un second texte qui est le relief (reste et aspérité) du premier: ce qu'il y a de délirant (d'interrompu) dans la raison des phrases.

[Fragment jest nie tylko odcięty od sąsiadujących z nim fragmentów, ale też wewnątrz każdego fragmentu króluje parataksa. Widać to wyraźnie, kiedy utworzy się indeks tych kawałeczków; dla każdego z nich assamblaż referentów jest heteroklityczny; jest to podobne do gry rymowanych kawałków: „Weźmy na przykład takie słowa: fragment, kolo, Gide, wolnoamerykanka, asyndeton, malarstwo, dysertacja, Zen, intermezzo; proszę sobie wyobrazić dyskurs, który mógłby je połączyč". Będzie to fragment, który właśnie piszę. Indeks tekstu jest nie tylko narzędziem referencji, ale już on sam jest tekstem, drugim tekstem, który jest reliefem (pozostałość i chropowatość) tekstu pierwszego: tak oto w rozumności zdań istnieje coś szalonego (coś bez związku).]

[OC, t. 4 , s. 670$]$

Konstrukcja tekstu Rolanda Barthes'a często opiera się na czymś, co on sam określał jako obrazek [tableautin]. To właśnie $\mathrm{z}$ tych małych obrazków Barthes układa tekst i w Mitologiach, i w Imperium znaków, ale także i w wielu innych tekstach. Jego pisanie polega często na łączeniu detali, które odbywa się poprzez dodawanie i zestawianie ze sobą owych obrazków lub fragmentów. Obrazki i fragmenty Barthes'a rzeczywiście są bardzo szczegółowe i maksymalnie wyczerpujące (decyduje o tym swoista gęstość języka, precyzja metafory), a jednocześnie

9 R. Barthes, Mitologie, przeł. A. Dziadek, wstęp K. Kłosiński, Warszawa 2000, s. 32 . 
otwarte, niedokończone, jak nieprzerwany tekst. Warto przytoczyć tu jeszcze i taki cytat z $R B$ :

[...] j'ai le goût préalable (premier) du détail, du fragment, du rush, et l'inhabileté à le conduire ver une "composition «: je ne sais pas reproduire „les masses”.

[(...) mam uprzednią (pierwotną) skłonność do detalu, fragmentu, gwaltownego zrywu, nie potrafię układać ich w "kompozycjęu: nie umiem odtwarzać „ogółu”.]

[OC, t. 4, s. 671]

Jest $w$ tym cytacie trochę prawdy, ale jest $w$ nim też właściwa Barthes'owi (przynajmniej w książce, z której cytat pochodzi) doza kokieterii.

Kolejne fragmenty tekstu ułożone są alfabetycznie w formie - mogłoby się zdawać - encyklopedycznych haseł (przychodzą na myśl autobiografie ułożone w formie abecadła, ale $R B$ odbiega od tradycyjnych książek tego typu). Barthes nie tworzy definicji poszczególnych słów, ale nazywa fragment - układanie fragmentów zgodnie $z$ porządkiem alfabetycznym pozwala uniknąć wszelkiej imitacji i wytwarza się w ten sposób porządek niemotywowany [OC, t. 4, s. 720-721] - struktura książki zostaje zręcznie usunięta. Jak dowiadujemy się od samego autora, fragmenty powstawały w różnej kolejności, w różnym czasie. Układając je w kolejności alfabetycznej, Barthes uzyskuje efekt zatarcia źródła historia zostaje ujęta w inny sposób, porozbijana, pokawałkowana. Poszczególne fragmenty stają się „symptomami” czy „tekstami symptomatycznymi" [OC, t. 4, s. 744]. Czasami jednak i w imię zasady heterogeniczności porządek alfabetyczny zostaje przerwany i wywołany zostaje w ten sposób szczególny efekt, w trakcie bowiem lektury zaczynamy wielokrotnie sprawdzać, czy składające się na tekst fragmenty rzeczywiście mają układ alfabetyczny. Jest to wyraźny sygnał adresowany do czytelnika: nie czuj się bezpiecznie, przestań przewidywać. Barthes nie daje się przyszpilić, usidlić - w trakcie lektury, w chwili, gdy wydaje nam się, że właśnie uchwyciliśmy już jakiś system, tekst natychmiast traci swój porządek, wykracza poza system, zaś czytelnik traci poczucie bezpieczeństwa, które daje konwencja i oswojenie.

Myślę, że trudno jest mówić o tej książce, przykładając do niej narzędzia wypracowane przez zewnętrzną wobec tekstu poetykę. Trudno jest o niej mówić, obierając trop podsunięty przez hermeneutykę, która zmierza do odsłonięcia ukrytego w dziele sensu czy jakiejś prawdy.

Jeśli chodzi o prawdę, to powstaje w przypadku $R B$ problem istotny $\mathrm{z}$ tego względu, że uwikłany $\mathrm{w}$ ciągłą grę czytelnik nie jest $\mathrm{w}$ stanie dosięgnąć prawdy. W konwencji autobiograficznej gwarantem prawdy staje się wyznanie, ale i tego przywileju - w końcu bardzo słusznie - odmawia swojej książce Barthes (fragment zatytułowany Lucidité [Jasność]): 
Ce livre n'est pas un livre de „confession”; non pas qu'il soit insincère, mais parce que nous avons aujourd'hui un savoir différent d'hier; ce savoir peut se résumer ainsi: ce que j'écris de moi n'en est jamais le dernier mot: plus je suis „sincère”, plus je suis „interprétable”, sous l'oeil d'autres instances que celles des anciens auteurs, qui croyaient n'avoir à se soumettre qu'à une seule lois: l'authenticité. Ces instances sont l'Histoire, l'Idéologie, l'Inconscient.

[Książka ta nie jest książką „wyznań”; nie dlatego, aby była nieszczera, ale dlatego, że dziś mamy nieco inną wiedzę o wczoraj; tę wiedzę da się podsumować w następujący sposób: to, co piszę o sobie, nigdy nie jest ostatnim stowem: w świetle zabiegów innych niż te dawnych autorów, którzy wierzyli w to, że podporządkowują się jednemu tylko prawu: autentyczności, jestem bardziej „szczery”, bardziej interpretowalny. Tymi zabiegami są Historia, Ideologia, Nieświadomość.]

[OC, t. 4, s. 696]

Czy zatem jest to prawdziwy obraz Barthes'a? I czy to pytanie słusznie jest $\mathrm{w}$ odniesieniu do tego tekstu postawione? Trudno uwierzyć $\mathrm{w}$ prawdziwość, zwłaszcza, kiedy odkrywamy wypowiedzi włączone w tekst i stojące na granicy śmieszności i kabotynizmu, np. fragment zatytułowany La côtelette [Żebro] [OC, t., 4, s. 640-641], zaczynający się od słów: „Oto, co pewnego dnia zrobiłem ze swoim ciałem”. Dalej następuje krótkie wyjaśnienie, w którym dowiadujemy się, że autor w związku z przebytą gruźlicą został poddany zabiegowi odmy płucnowej, w trakcie którego odjęto mu kawałek żebra. Żebro przeleżało w szufladzie sekretarzyka wśród rozmaitych „skarbów”, po czym: „pewnego dnia, kiedy zrozumiałem, że funkcją każdej szuflady jest złagodzenie, oswojenie śmierci przedmiotów poprzez umieszczenie ich $w$ miejscu pełnym czci [...], nie ośmielając się jednak wyrzucić żebra na śmietnik, wyrzuciłem je wraz z kawałkiem gazy, w który było owinięte, z balkonu na ulicę Servandoni (jakbym romantycznym gestem rozsypywał swoje własne prochy), gdzie wywęszył je pewnie jakiś pies." Takich fragmentów, niemal domagających się parodii, jest w tekście $R B$ znacznie więcej. Nawiasem mówiąc, dzieło Barthes'a doczekało się parodii w postaci książki Michel-Antoine'a Burniera i Patricka Rambauda Le Roland-Barthes sans peine [Roland Barthes bez trudu $]^{10}$ - autorzy dali się zresztą złapać w zastawioną przez Barthes'a pułapkę odsłaniającą związek parodii z Doksą.

W przypadku $R B$ powstaje problem zasadniczy: jakże odsłaniać sens $\mathrm{w}$ dziele, które z założenia sens odrzuca? Jak nadać sens dziełu, które deklaratywnie usiłuje za wszelką cenę uciekać od sensu, odpychać sens? Sam autor - zresztą w recenzji swojej własnej książki napisał (odczytuję ten skrajny gest jako ostateczne potwierdzenie dystansu wobec siebie

${ }^{10}$ M.-A. Burnier, P. Rambaud, Le Roland-Barthes sans peine, Paris 1978. 
samego i ostateczne potwierdzenie niemożliwości określenia swojej własnej tożsamości, jeśli traktuje się ją jako coś stabilnego, co jest ułożone centralnie wobec ludzkiej osoby), że jest to książka: „zdaje się napisana wyłącznie w celu odrzucenia sensu"11. Czytając tę książkę, trzeba przyjąć pozycję tropiciela nie tyle ukrytych w niej sensów, ile reguł i przymusów ich wypracowywania ${ }^{12}$ (tym bardziej że w późnych pracach Barthes'a nie ma jednoznacznych określeń pojęcia sensu, jest ono bowiem zwykle dookreślane za pomocą takich epitetów: „rozedrgany" [ frémissant], „drżący” [frissonant], "trzęsący się" [tremblé], „pogmatwany” [brouillé], „zmienny” [labile], "chwiejny" [indécis]) - oto jest trudne zadanie, jakie stawia Barthes przed czytelnikiem swojej książki.

Wychodzę $\mathrm{z}$ założenia, że zagadnienie tożsamości jest autentycznie najważniejszym problemem w Barthesowskiej narracji o sobie samym. Zasadnicza kwestia, jaka się tu pojawia, sprowadza się do następującego problemu: w jaki sposób można określić czy zdefiniować własną tożsamość, czy w ogóle da się to zrobić? Jeśli zaś nie można tego uczynić, to co stoi na przeszkodzie zamierzonego w tym celu działania?

Raz jeszcze powtarzam pytanie: czy w ogóle można uznać ten tekst za autobiografię? Czy warto podejmować próby klasyfikacji, która na zawsze pozostanie w odniesieniu do $R B$ niepełna, niedookreślona, będzie się bowiem rozmywać i zacierać $\mathrm{w}$ polu autoanalizy, autotematyzmu i autoreferencji?

Barthes pyta, jak jest możliwe opisanie (czy raczej napisanie) siebie samego? Jego przewrotny tekst koncentruje się na trybie narracji o sobie i odsłania, natarczywie wskazuje czytelnikowi tekst w tekście, który bezustannie dekonstruuje narrację o sobie samym, „dekonstruuje ontologiczne podstawy tekstu autobiograficznego"13:

Je ne dis pas: „Je vis me décrire”, mais: „J'écris un texte, et je l'apelle R. B." [...] Ne sais-je pas que, dans le champ du sujet, il n'y a pas de referent? Le fait (biographique, textuel) s' abolit dans le signifiant, parce qu'il coincide immédiatement avec lui [...] jes suis moi-même mon propre symbole, je suis l'histoire qui m'arrive: en roue libre dans le langage, je n'ai rien à quoi me comparer, et dans ce mouvement, le pronom de l'imaginaire, ,je", se trouve im-pertinent; le symbolique deviant à la letter immédiat: danger essentiel pour la vie du sujet: écrire sur soi peut paraître une idée prétentieuse; mais c'est aussi une idée simple: simple comme une idée de suicide.

11 R. Barthes, Barthes puissance trois, w: tegoz, OC, t. 4, s. 775 .

12 Por. R. Barthes, Qu'est-ce que la critique? w: tegoż, OC, t. 2, s. 506.

$13 \mathrm{P}$. Jay, Being in the Text. Self-representation from Wordsworth to Roland Barthes, London 1984, s. 177. 
[Nie mówię: „Opiszę siebie”, ale „Piszę tekst i nazywam go R. B.” [...] Czyż nie wiem, że $w$ polu podmiotu nie ma referentu? Fakt (biograficzny, tekstowy) zostaje zniesiony w signifiant, bowiem wchodzi $\mathrm{z}$ nim natychmiast w relację koincydencji [...] sam jestem swoim własnym symbolem, jestem historią, która mi się przytrafia: na wolnym biegu języka nie mam się do czego porównać, a w tym ruchu wyobraźniowy zaimek,$j a "$ staje się bez-sensowny; symbolika staje się dosłownie bezpośrednia: prawdziwe niebezpieczeństwo dla życia podmiotu: pisanie o sobie może się wydać pretensjonalne; ale jest to również prosta idea: prosta jak idea samobójstwa.]

[OC, t. 4, s. 637]

Barthes wprowadza do swojego tekstu cztery maski czy też - jak sam je określa - „persony językowe”: „ja” (pojawiające się w tekście stosunkowo rzadko), „pan” (forma podobna do „pan” z pism de Sade'a, umożliwiająca „odczepienie” piszącego od podmiotu), „R. B.” (pojawiająca się wszędzie tam, gdzie „on" byłby formą niejasną czy dwuznaczną) oraz, najważniejsza z wszystkich wymienionych, forma „on" - żadna z nich nie jest „ja” rzeczywistym, wszystkie są znakiem dystansu i różnicy, w której bezustannie rozmywa się tożsamość. Autor najczęściej posługuje się trzecią osobą - ,ja” mówi o sobie „on" i nie chodzi tu w żadnym razie o nawiązanie do konwencji autobiograficznej, w której taka forma osobowa nie jest niczym niezwykłym (w takim wypadku wiąże się to najczęściej z emfazą, nadaniem ważności swojej własnej osobie), ale raczej o podkreślenie odrębności, dystansu dzielącego ja rzeczywiste od ja tekstowego. Ostatecznie - sugeruje Barthes w jednym z wywiadów zamieszczonych w Le grain de la voix - to sam czytelnik ma rozstrzygnąć, w jaki sposób należy traktować zaimek „on”: „mówienie o kimś "on « zmierza do jego unieobecnienia, uśmiercenia"14.

Jeśli Barthes mówi o sobie w trzeciej osobie, to widać tu niewątpliwie wpływ Brechta, który nakazywał swoim aktorom dystans wobec postaci - chodziło nie tyle o to, aby wcielić się w daną postać, ale ją pokazać "na sucho" czy też "na czczo" (autor podpowiada takie wyjaśnienie we fragmencie zatytułowanym właśnie $A$ jeun [ $\mathrm{Na} \mathrm{czczo}$ ), chodzi o to, aby oddzielić zaimek od rzeczownika (aktor Brechta miał myśleć swoją rolę w trzeciej osobie):

Comment préparer la meilleure lecture de moi-même que Je puisse espérer: no pas aimer, mais seulement supporter à jeun ce qui a été écrit?

[W jaki sposób przygotować najlepszą z możliwych lektur siebie samego: nie chodzi o to, aby mi się to podobało, ale aby to, co zostało napisane, było do zniesienia na czczo.]

[OC, t. 4, s. 686]

${ }_{14}$ R. Barthes, Le grain de la voix. Entretiens 1962-1980, Paris 1981, s. 204; Przedr. w: OC, t. 4 , s. 860 . 
Jest jeszcze inne wyjaśnienie tak częstego użycia zaimka „on”; mianowicie, jeśli Barthes mówi o sobie w trzeciej osobie, to przyczyną jest również szczególne rozumienie podmiotu i podmiotowości. „Podmiot jest wyłącznie efektem języka" [OC, t. 4, s. 656] - czytamy w jednym z fragmentów $R B$, w którym autor postuluje stworzenie nowej nauki o podmiocie, która opisywałaby nowy typ podmiotu.

Podmiot pisania nie da się tu w żaden sposób sprowadzić do suwerennej jedności pisarza. Jawi się on tutaj jako system relacji pomiędzy warstwami: bloku magicznego, psychicznego, społeczeństwa, świata, toteż na scenie pisania nie da się odnaleźć punktowej prostoty klasycznego podmiotu15, pojętego w kategoriach zachodniej filozofii jako podmiotu wiedzy, prawa czy świadomości (Kartezjusz, Kant, Husserl).

Barthes nie rozumuje zgodnie $\mathrm{z}$ paradygmatem subiektywność/obiektywność, co więcej, odrzuca opozycje binarne oparte na przeciwieństwie lub sprzeczności - tzw. „podmiot podzielony” nie wiąże się według niego ze sprzecznością, ale z dyspersją. Zaimek osobowy ,ja" [je] nie musi się odnosić do „ego" [moi] - zgodnie z jego rozumowaniem, „ja rzeczywiste” nie jest ,ja wyobraźniowym" (tym wpisanym w tekst). Stąd wynika potrzeba mówienia o sobie w formie „on" w wypowiedzi o sobie samym. Konsekwentnie i zgodnie $\mathrm{z}$ tym trybem myślenia można napisać recenzję ze swojej własnej książki, w której nadal używa się formy „on” - przy czym „on" z recenzji nie jest już tożsame $\mathrm{z}$ „on" z $R B$.

Bezpośrednimi intertekstami $R B$ (interteksty rozumiem tu jako zbiór tekstów i myśli autorów, którzy w znaczący sposób wpłynęli na model myślenia i pisania przyjęty przez Barthes'a, ale też pozostawili swój wyraźny ślad w tekście $R B$ ) są Nietzsche (chodzi zwłaszcza o silne tendencje moralizatorskie, łatwe do uchwycenia w wielu fragmentach tekstu) i Lacan. W samym tekście $R B$ istnieje wiele nawiązań do myśli Lacana, $\mathrm{np}$. jedna $\mathrm{z}$ fotografii przedstawiająca matkę $\mathrm{z}$ niemowlęciem została podpisana tytułem słynnego wykładu Lacana Le stade $d u$ miroir ${ }^{16}$ (pełny podpis fotografii zawiera dodatkowo cytat $\mathrm{z}$ ostatniego akapitu wykładu Lacana; „Le stade du miroir: "tu es cela»" - „Stadium lustra:

15 Por. J. Derrid a, Pismo i różnica, przeł. K. Kłosiński, Warszawa 2004, s. 395.

$16 \mathrm{~J}$. Lacan, Le stade du miroir comme formater de la fonction du Je telle qu'elle nos est révélée dans l'expérience psychanalytique, w: tegoż, Écrits I. Paris 1971, s. 89-97.; J. Lacan, Subvertion du sujet et dialectique de désir dans l'inconscient freudien, w: tegoż, Écrits, Paris 1966, s. 793-827. Por. też: T. Eagleton, Psychoanalysis, w: tegoż, Literary Theory. An Introduction, Oxford and Cambridge 1992, a także: B. Ogilvie, Lacan. La formation du concept de sujet, Paris 1987. Steffen Nordahl Lund, dokonując lektury dzieła Barthes'a w kontekście teorii znaku, kładzie szczególny nacisk na relację podmiot/ signifiant. Zob. S. N. Lund, L'aventure du signifiant. Une lecture de Barthes, Paris 1981, s. 73-80. 
"to ty"), omawiającego kwestię kształtowania się podmiotu w ramach języka opartego na bezustannym przemieszczaniu się signifiants.

Przedstawioną $\mathrm{w}$ szkicu Lacana sytuację dziecka spoglądającego w swoje lustrzane odbicie można odczytać jako metaforę znaku, gdzie signifiant i signifié są harmonijnie połączone (dziecko przeglądające się w lustrze - to signifiant, zaś jego lustrzane odbicie, obraz, który widzi - to signifié). W tym jednym momencie podmiot jest pewnego rodzaju jednością, pełnią, dziecko jest całkowicie szczęśliwe. Dopiero moment wkroczenia w język, moment przejęcia języka (odkrycie różnicy seksualnej) jest tym dramatycznym punktem, który burzy porządek szczęścia i pełni. Od tego momentu osiągnięcie całości staje się niemożliwe, aby ją osiągnąć bowiem, trzeba przemieszczać się od signifiant do innego signifiant wzdłuż nieskończonego łańcucha języka. "Metaforyczny” świat lustra został zastąpiony "metonimicznym” światem języka, co oznacza nieskończone przesunięcie, niemożliwość osiągnięcia jakiegoś stałego punktu. Konsekwencją powstania tego nieskończonego łańcucha jest bezustanny podział i bezustanne różnicowanie każdej tożsamości.

Osiągnięcie jedności i pełni, co było możliwe jedynie w fazie przededypalnej, sprowadza się po jej przekroczeniu do ciągłego przechodzenia od substytutu do substytutu, od metafory do metafory. Zdaniem Lacana, nieświadomość, która jest ustrukturowana podobnie jak język, polega na wślizgiwaniu się signifiés pod signifiants. Stąd też sens podlega prawu ciągłego zanikania. Proces mowy jest ulotny, dlatego też nie możemy jednoznacznie powiedzieć tego, co chcielibyśmy powiedzieć. Sens jest zawsze tylko przybliżony i nigdy nie możemy powiedzieć prawdy $\mathrm{w}$ sposób jednoznaczny, całkowicie czysty. Podmiot wypowiadający, osoba mówiąca lub pisząca nigdy nie może całkowicie przedstawić siebie w tym, co mówi, ponieważ nie istnieje żaden znak, który mógłby stworzyć sumę jego całości. Nawet, jeśli uźywa się zaimka osobowego ,ja”, to pełni on jedynie funkcję figuratywną, podmiot jest zawsze nieuchwytny, zawsze bowiem musi dokonać się jego przejście przez język. Oznacza to, że nigdy nie można jednocześnie „znaczyć” i „być”.

Barthes $\mathrm{z}$ pełną świadomością $\mathrm{i}$ konsekwentnie konstruuje swój tekst, opierając się na psychoanalizie. Co więcej, terminologia psychoanalityczna jest wprost rozsiana po calym tekście $R B$ (stadium lustra, kompleks Edypa, kastracja, fantazmat, symptom, Fort/Da) i tworzy coś na kształt wewnętrznego tekstu tej książki - własny tekst Barthes'a, jego własne wypowiedzi znajdują się pod bezustannym nadzorem mówiącego, pod jego obserwacją. Sam podmiot mówiący przyjmuje tu pozycję psychoanalityka nastawionego na wyłapywanie signifiants swoich własnych wypowiedzi. $R B$ nie stanowi więc jakiegoś novum w zakresie dyskursu autobiograficznego, ale raczej próbę autopsychoanalizy. 
Zasadnicza kwestia wyłaniająca się $\mathrm{z}$ tej niezwykłej książki wiąże się z tym, że narracja o sobie może być wyłącznie fragmentaryczna, wybiórcza i zawsze niedokończona, otwarta, uwikłana w niekończący się tekst. $R B$ par $R B$ zbliża się tym samym - jak pozornie mogłoby się wydawać - do utopii. Jednak chodzi tu nie tyle o utopię, ile zadeklarowaną atopię (od greckiego atopos, które oznacza "nie na swoim miejscu”):

Fiché: je suis fiché, assigné à un lieu (intellectuel), à un résidence de caste (sinon de classe). Contre quoi une seule doctrine intérieure: celle de l'atopie (de l'habitacle en dérive). L'atopie est supérieure à l'utopie (l'utopie est réactive, tactique, littéraire, elle procède du sens et le fait marcher).

[Wtrącony: jestem wtrącony w pewne miejsce (intelektualne), jakąś siedzibę kasty (jeśli nie klasy). Jedynym na to sposobem jest wewnętrzna doktryna: atopii (dryfującego przybytku). Atopia jest nadrzędna wobec utopii (utopia jest reakcyjna, taktyczna, literacka, operuje sensem i wprawia go w ruch).]

[OC, t. 4, s. 629]

Pomijając oczywistą kwestię społecznej referencji tej wypowiedzi, warto w tym miejscu zwrócić uwagę na fakt, że wspomniana w niej „doktryna atopii” odnosi się również do sytuacji podmiotu mówiącego i do zagadnienia tożsamości. Pojawiający się w tym cytacie termin „atopia” oznacza przede wszystkim bycie "nie na swoim miejscu”, ale też może oznaczać bycie „bez miejsca” czy „brak miejsca”, atopia to również „idiopatia" i „niezwykłość". Barthes snuje narrację o swojej tożsamości za pomocą tekstu, który podlega bezustannej dekonstrukcji, bezustannej rozbiórce - mówiąc metaforycznie - „tekstu dryfującego”. Czy istnieje jakiś skuteczniejszy model narracji o sobie? 